\title{
Civil Service Property Declaration System in U.S. and Its Enlightenments to China
}

\author{
Li Yongkang, Yan Zhen \\ School of Public Management, Yunnan University of Economics and Finance, Kunming, \\ P.R.China, 650221 \\ (Email: 121651831@qq.com, 1183437229@qq.com)
}

\begin{abstract}
Civil service property declaration system (CSPDS) is an important means to effectively prevent the occurrence of civil servant corruption. The methods of literature and comparative analysis are used in this article to describe in detail the composition of U.S. CSPDS. On this basis, the following characteristics are drawn: step-by-step legislative process; wide-ranging and comprehensive property declarers; independent investigation and management agencies; severe punishment for illegal behaviour; cultivating public awareness to enhance social supervision and against corruption; perfect supporting measures. And then three enlightenments are put forward to improve of civil servants property declaration system in China by speeding up legislation, perfecting independent managing institutions and enhancing the social supervision.
\end{abstract}

Keywords: The United States; Civil Service Properties Declaration System; Legislation; Independent Investigation institutions; Social Supervision

\section{Introduction}

Civil Service Property Declaration System(CSPDS) is a legal system that civil servants report their legal property to the relevant managing authorities based on the statutory deadline and way, and accept supervision and inspection from relevant authorities within the statutory range and all aspects. Sound CSPDS contributes to addressing the difficulties of administrative ethics , protecting the public right to know and supervise, promoting democracy, fighting against corruption and establishing the government of sunshine.

David H. Rosenbloom (2002), a famous American administrative scholar, starting from the reasons that public administrators need to be supervised and the difficulties of supervision, proposes making use of public disclosure to reveal improper or unethical administrative activities and generate internal sense of responsibility by internal control to build a Sunshine Government. Chinese scholars in recent years have introduced foreign official property declaration system and the status of implementation. Ma Guoquan (1999) introduced U.S. civil service moral codes. Zhou Pan and Yan Yongrong (2008) analyzed the decentralized admissibility mode of the civil service property and supporting systems such as blind trusts, personal credit, which is perfect to show the contents of the
United States property declaration system. Li $\mathrm{Ci}$ (2009) from the Summers' property declaration storm, analyzed the social values and legislative characteristics of U.S. CSPDS. Wang Ying (2010) described the range of declarers in U.S. CSPDS and the seven items defined by Constitution, Congress.

This article focuses on the content and features of U.S. CSPDS, and tries to analyze its reference value in the establishment of CSPDS in China.

\section{The Structure of U.S. Civil Service Properties Declaration System}

\subsection{Declarers and Contents of Property Declaration}

Within the executive branch, senior officials of the annual salary of $\$ 50,000$ or more , such as the legislative, administrative, judicial and other federal agencies, are required to reporting. Ethics Reform Act of 1989 specifically provided for three categories of personnel required property declaration: First, all government officials, including White House officials; Second, Members of the Senate and House of Representatives and their employees; Third, judges and judicial employees. (Li Ci, 2009)

The United States civil servants need to declare four category property. The first category is the property and income. Property 
includes securities, bonds, pension, survivor pension, tax sheltered annuity, personal savings, mutual funds, real estate, self-produced food, livestock, collectibles for sale and investment as well as any for investment or income-producing property. Income consists of investment income and labor income. Investment income refers to interests, rents, royalties, dividends, capital gains, etc., which applicants, their spouses and dependent children obtained from their property and operation. Labor income includes wages, commissions, service fees, lecture submission fee, as well as other labor compensation. The second category is trading activity, which refers to the results of applicants, their spouses and dependent children's real estate, securities, bonds, mutual funds, stocks and other securities sale and exchange. The third category is gifts and reimbursement. The applicant must declare themselves and their spouses and dependent children to receive food, lodging, transportation, gifts and entertainment, compensation, benefits, and other valuable gifts. The fourth category is the debt and employment situation. The applicant must declare themselves and their spouses and dependent children of any debt of more than \$ 10,000. At the same time, applicants must report all paid and unpaid part-time circumstances in society.

\subsection{The Audit Procedures of Property Declaration}

The United States has a comprehensive property audit program. Within the executive, legislative and judiciary systems, property declared admissible authorities accept declaration and audit respectively. On one hand, in administrative system the Office of Government Ethics and professional ethics officer are responsible for the review of the administrative official property declaration, and check list of property whether there is any conflict of interest related to one's position. The suspicious property must be reported to the Minister of Justice, and then he will appoint a court prosecutor to investigate the suspicious property. On the other hand, FBI will also conduct background checks on government officials, to fully grasp civil servants' property status, economic relations, social relations, to confirm their communication, character, reputation, loyalty, etc.

\subsection{Supervisory Authority and Its Functions}

OGE (U.S. Office of Government Ethics, 2013), established by the Ethics in Government Act of 1978, is the independent government agency led by the President and Congress and provides overall direction, oversight, and accountability of Executive Branch policies designed to prevent and resolve conflicts of interest. The mission of OGE is to foster high ethical standards for executive branch employees and strengthen the public's confidence that the Government's business is conducted with impartiality and integrity. OGE is also charged with promoting high ethical standards for Executive Branch employees. Specifically, OGE is responsible for:

Promulgating and maintaining enforceable standards of ethical conduct for over four million civilian employees and uniformed service members in over 130 Executive Branch agencies

Overseeing a financial disclosure system that reaches more than 28,000 public filers and over 325,000 confidential filers

Ensuring that Executive Branch ethics programs are in compliance with laws and regulations

Providing education and training to the more than 5,700 ethics officials, as well as executive branch employees

Conducting outreach to the general public, the private sector, and civil society

Sharing good practices with, and providing technical assistance to, state, local, and foreign governments and international organizations

\subsection{Punitive Measures for Violations}

The Ethics in Government Act of 1978 and Ethics Reform Act of 1989 provide for conflict of interest violations and abuses in the property given severe punishment measures. Depending on the circumstances and the legal authority at issue, an executive branch employee may be imprisoned, fined, demoted, or fired for violating an ethics provision. The organ can make a direct penalty to the officials who refuse, delay or lie to report property. The Justice Department may institute civil proceedings against the parties, and the Court can sentence a fine of less than $\$ 10,000$. Those who deliberately provide false information are instituted against by Criminal proceedings, and also are sentenced to a fine of up to $\$ 250,000$ or 5 years ' imprisonment. Public officials who submit false registration of property, or do not register property, not declare a change issues and foreigners gifts, not illustrate the material, will be dismissed or punished by Civil Ethics Committee. Those who break the Law on Conflict of Interest will be sentenced to punishment of less than $\$ 10,000$ or 2 years of imprisonment, or both penalties. 


\subsection{Public Disclosure System}

Ethics Reform Act of 1989 provides that officers who belong to publicly declare should report their personal property to the public, and any citizen can view or copy. Within 15 days after the end of the property declaration, reporting information should be available to the general public after 6 years, except for illegal access or public disclosure that will harm national interests.

The United States has adopted the principle of limited public. Officials who act as endowed with important decision-making authority and command, senior scientific and technical personnel, consultants, must publicly declare the status of the property for themselves and their spouses and dependent children. Confidential reporting officers are decided by each department, which applies to lower-level officials and employees.

By disclosure of information into book on the statutory place, reviewers simply indicate in writing their own name, occupation, address, objective content and requirements to access property information. The application materials of officials at all levels in key position are open in the relevant public press.

\subsection{Supporting Systems}

Blind trust is an arrangement whereby a person places some or all financial affairs in trust, beyond his personal control. In Property Declaration System, blind trust means that clients do not know their property depending on which trust agent, and trustees do not know where their property belonging to a client, to achieve the double-blind trust for government officials and professional financial trust. Government through the implementation of a blind trust reduces the phenomenon of public power to seek personal interests, and avoid collusion between officials and the trust in the reports of property.

On the credit system, United States implements market-oriented trust management model which includes the credit status of individual family, credit overdraft borrowing and repayment, assessing, recording, archiving, personal credit rating. Credit services are provided by the private sector, while the government is responsible for the regulatory oversight of credit executive. The credit bureaus provide credit reports to consumers or legal institutions and individuals.

\section{Characteristics of the United States Civil Service Property Declaration System}

\subsection{Step-by-Step Legislative Process}

In 1925, the United States promulgated the Corrupt Practices Act, which declared candidate property. In 1951, Administrative Department's Ethical Standards required government officials to the property declaration, and require parliamentary legislation. The Ethics in Government Act of 1978 provided for ethics and conduct of the legal constraints on government officials. Ethics Reform Act of 1989 formally established the legal form of official property declaration system. After nearly ninety years of exploration, the United States has gradually formed a systematic legal system by refining the subject and content of the property declaration system, which establishes the concept of property declaration of civil service, and helps build a clean and efficient government. The federal government of the United States in nearly three decades of the implementation process of the property declaration, has increased the rules and regulations of the property declaration to build a comprehensive civil service management system and focus on the public power and interests in the government reform.

\subsection{Wide-Ranging and Comprehensive Property Declarers}

To avoid the erosion of the public interests by public officials, the United States implements a wide-ranging and comprehensive property declaration system. Whether to report openly is decided by the level and position of officials. The officials who need to report their property publicly typically are advanced scientific and technical personnel, consultants and important policymakers and commanders. The United States declares detailed provisions of the range of property declaration, in which applicants and their spouses and dependent children must declare income and gifts, transportation, housing. In this way, civil servants publish personal property, real property, debts. By checking "grey" or even "black" incomes, censors can more timely find and uncover false and falsified accounts, so that civil servants do not dare to bribe and accept bribes.

\subsection{Independent Investigation and \\ Management Agency}

The Office of Government Ethics (OGE) is an independent agency, under the leadership of President directly, reporting to the President 
and Congress. Members of the Senate and the House of Representatives, White House officials are required to submit property declarations, and actively declare their property. Judicial ethics committee in federal court is responsible for the review and management reporting data of the admissibility of assets declaration of judges and judicial employees.

\subsection{Severe Punishment for Illegal Behaviour}

The Ethics in Government Act of 1978 and United States Code clearly provide that administrative, judicial and legislative have right to audit. The information of refusal to declare or false property declarations will be reported to the Minister of Justice in time. Strict punitive measures are taken for different violations. In accordance with the law, relevant litigants will be punished by the means of fines, civil litigation, criminal procedure and imprisoning. By efforts to increase the penalties for violations, the government takes a warning to civil servants and maintains the role of social justice.

\subsection{Cultivating Public Awareness to Enhance Social Supervision and Against Corruption}

The United States governments fully mobilize the power of supervision of the community and stimulate the enthusiasm of the citizens' political oversight. Citizens who write their name, occupation, address, the content and purpose of query can check the status of the property of the relevant official. The investigation of property audit on the fame and life experience of the officials is using indirectly the strength of masses to check authenticity of civil service information. Conduct of civil servants accepting the public oversight and property of civil servants subjecting to public inquiries make the public expose corruption by using the reporting procedures. Establishing the concept of anti corruption is the responsibility of the judiciary, as well as civic duty.

\subsection{Perfect Supporting Measures}

Civil service property declaration not only needs to declare the constant improvement of the system itself, but also to establish the appropriate supporting measures. In the United States the real-name system of the financial accounts is implemented and the accurate financial and computer network is used to grasp the status of every citizen in the country. At the same time, system of property assessment is used to compare between the officials' declaring property and actual property in order to ensure the accuracy of the property declaration. Furthermore, after the establishment of national financial electronic and personal credit system of the whole society, the United States government can manage systematically and scientifically civil service property, and increase the cost of non-compliance of dishonesty, and create the culture of honesty and integrity.

\section{Enlightenments to Civil Service Property Declaration System in China}

At present, property declaration system in China has been attracted the attention of scholars. Li chuan wei and Du bao gui (2009) described the history of the development of the civil service property declaration system, the practical significance of the property declaration system, and the way of the improvement of China's property declaration system. Yang Jie (2010) discussed the basis, problems and countermeasures of property declaration system in China, and found the barriers of the implementation of the property declaration from ideological obstacles, imperfect supporting facilities. Li CI (2010) discussed the effective construction of property declaration system in China and introduced the property declaration system of the leading cadres in Xinjiang Aletai region.

Property declaration is a process of continuous practice. In 2008, Altay Prefecture in Xinjiang first proposed the provisions of the declaration of property, which was a milestone in the development of property declaration system in China. In 2009, the national cadre supervision meeting clear to the implementation of the relevant matters of personal property explored the property declaration system of cadres in selecting and appointing. Xiangshan county in Zhejiang Province, Beijiang District in Chongqing, Hengyang city in Hunan Province, Yinchuan city in Ningxia Province have implemented property declaration system of the leading cadres. In July 2010, Provisions About the Leading Cadres to Report Personal Matters pointed clearly that officers who are sub-division level and above are required to report including income, real estate and investment, marriage change, spouses and children emigrated abroad.

$\mathrm{Xi}$ Jinping as general secretary of the CPC Central Committee at the beginning of his term of office has paid attention to the construction of anti-corruption. Therefore, it is particularly important and urgent to learn the advanced experience from the United States property declaration system, and gradually improve Chinese civil service property declaration 
system.

\subsection{Speeding up Legislation of the Property Declaration}

In accordance with the experience of step by step improving legislation in United States nearly ninety years, the first step of improving Chinese civil servants property declaration system is to accelerate the legislation. Our current official property declaration system is primarily based on Provisions on Income Declaration of the Leading Cadres above County Level at the Party and Government Organs of 1995, Provisions on Leading Cadres at the Provincial Level to Report the Family Property (Trial) of 2001, and Certain Provisions on the CPC Central Commission for Discipline Inspection to Strictly Prohibit the Use of His Position to Seek Illegitimate Interests of 2007, Provisions on leading cadres report personal matters related of 2010, which are not systemic and at a low level of legislation.

Legislation of property declaration needs to be clearly defined on declarers, content, manner. First , declarers of property declaration should be implemented classified management. The greater power means the greater possibility of corruption and social harm. The property declaration should start from senior leaders who have great administrative powers so that they open their status of property and accept social supervision. Property declaration should include the property status of the officials, their spouses and minor children, to reduce the tendency of transferring of property to circumvent the checks. Second, the content of property declaration should include four categories from U.S. experience to limit and abolish illicit income. Third, on the manner of property declaration, the leaders of civil service should open their status of their property to public and accept the inspection and supervision from society. The internal reporting applies to non-leadership positions of civil service.

\subsection{Perfecting Independent Managing Institution}

The experience of DGE in the United States illustrates that it is necessary and meaningful to establish a relatively aloof and independent property declaration agency. National Bureau of Corruption Prevention of China as an institution directly under the State Council manages property declaration of the civil service. To form the perfect management system, a management system should be set in local whose function is similar to the central management agency, but whose organization and personnel relations are independent, to accept and check property of the civil service.

To stress the timeliness of the property declaration, the government could stipulate that civil servants at all levels submit their property reports to the regulatory agencies at a certain time, such as annually from January 1 to 31 . The regulatory agencies have right to give those who do not submit their property reports a written notice, and require an explanation within a certain period. Bureau of Corruption Prevention should input personal identify of civil servants into system to check whether verification registration of estate, wages and number of securities is real or not. Those who can not explain the legitimate source of property should be investigated and hold criminally responsible.

\subsection{Improving the System of Social Supervision}

America has a developed civil society and relatively independent oversight powers so that officials face strict supervision mechanisms. Its enlightments to China is to develop a sense of anti-corruption of civic, innovate communication channels and facilitate the right of supervision of citizens. Legislation of property declaration should confirm the way of publicity of the property declaration of civil service through official government newspapers, websites. The reports of property declaration accept inquiries from the public. The institution of property declaration reviews the applicant's name, occupation, query content and purpose, and provides the corresponding query service to legitimate applicants.

The supervisory authority must investigate the officials who have illegal and undeclared property in accordance with the law. The citizen who provide official's illegal and undeclared property are required to give appropriate evidence and assist in the investigation. The findings are publicized within the prescribed period to correct the violation or illustrate the property declaration of official which do not have any problem to remove doubts of the citizens. Only the government realizes the importance of social supervision, public can increase trust to government work and identity.

\section{Conclusion}

This article introduces the composition of U.S. CSPDS: declarers and contents, audit procedures of property declaration, supervisory authority and its functions, punitive measures for violations, public disclosure system and 
supporting systems. Its characteristics include six points: step-by-step legislative process, wide-ranging and comprehensive property declarers, independent investigation and management agency, severe punishment for illegal behaviour, cultivating public awareness to enhance social supervision and against corruption, perfect supporting measures. There are three enlightenments to China: speeding up legislation of the property declaration; perfecting independent managing institution; improving the system of social supervision. They are very important to improve Chinese CSPDS.

\section{References}

[1] David H. Rosenblum, Robert S. Kravchuk. Public Administration: Understanding Management, Politics and Law in the Public Sector (fifth edition). Beijing: China Rennin University Press, 2002 (12): 554-580. (In Chinese)

[2] Zhou Pan, Yan Yongrong. International Experience of Civil Service Property Declaration System. Social Sciences Review. 2008 (12): 368-370. (In Chinese)

[3] Li Ci. Property Declaration System of U.S. Civil Service and Its Revelation--Speaking from Summers’ Property Declaration Storm. Journal of Yunnan Administration College. 2009 (5): 139-142. (In Chinese)

[4] Wang Ying. U. S. Civil Service Property Declaration System. Knowledge/ Monthly. 2010 (8): 44-45. (In Chinese)

[5] Li Chuanwei, Du Baogui. The Plight and Way out of Chinese Civil Service of Property Declaration System Theoretical Circles. 2009 (9): 52-53. (In Chinese)

[6] Yang Jie. The Base, Problems and Countermeasures of Implementation of Property Declaration System. Academic Forum. 2010 (9): 31-36. (In Chinese)

[7] Tai Zuyan. The Status of Implementation of Foreign Official Property Declaration System and Revelation. Leadership Science. 2010 (7): 4-6. (In Chinese)

[8] Ma Guoquan. U.S. Civil Service and Ethical Codes. Beijing: Qinghua University Press, 1999 (5). (In Chinese)

[9] U.S. Office of Government Ethics .2013. http://www.oge.gov- Mission \& Responsibilities

[10] National Bureau of Corruption Prevention of China.2013. http://www.nbcp.gov.cn (In Chinese 